\title{
Література
}

1. Гильбух Ю. 3. Внимание : одаренные дети / Юрий Зиновьевич Гильбух. - М. : Знание, 1991 - 80 с. 2. Костюк Г. С. Навчально-виховний процес і психічний розвиток особистості / Г. С. Костюк ; за ред. Л. П. Проколієнко. - К. : Рад. школа, 1989. - 308 с. 3. Лейтес Н. С. O признаках детской одаренности / Н. С. Лейтес // Вопросы психологии. - 2003. - № 4. - С. 13-18. 4. Леонтьев А. А. Основы психолингвистики / Алексей Алексеевич Леонтьев. - М. : Смысл， 2005. - 288 с. 5. Матюшкин А. М. Концепция творческой одаренности / А. М. Матюшкин // Вопросы психологии. - 1989. № 6. - С. 29-33. 6. Методика навчання української мови в середніх освітніх закладах / М. І. Пентилюк, С. О. Караман, О. В. Караман, О. М. Горошкіна, 3. П. Бакум й ін. ; за ред. М. І. Пентилюк. - К. : Ленвіт, 2004. - 400 с. 7. Немов Р. С. Психология / Роберт Семёнович Немов. - М. : Просвещение, 1995. - 372 с. 8. Рубинштейн С. Л. О мышлении и путях его исследования / Сергей Леонидович Рубинштейн. - М. : Изд-во Акад. наук СССР, 1958. - 147 с. 9. Теплов Б. М. Способности и одаренность / Б. М. Теплов // Психология индивидуальних различий : Тексты / под ред. Ю. Б. Гиппенрейтер, У. Я. Романова. - М. : Изд-во Моск. ун-та, 1982. С. 129-139. 10. Фіцула М. М. Педагогіка : [навч. посіб.] / Михайло Миколайович Фіцула. - [2-ге вид., виправл., доповн.]. - К. : Академвидав, 2006. - 560 с. 11. Холодная М. А. Когнитивные стили и интеллектуальные способности / М. А. Холодная // Психологический журнал. - 1993. - № 1. - Т. 13-б. - С. 84-93. 12. Чудновский В. Э. Одарённость : дар или испытание / В. Э. Чудновский, В. С. Юркевич. - М. : Знание, 1990. - 80 с.

Інна Кравцова

\section{ФОРМУВАННЯ І РОЗВИТОК НАВИЧКИ ВИРАЗНОГО ЧИТАННЯ В УЧНІВ ПОЧАТКОВОЇ ШКОЛИ В КОНТЕКСТІ НОВОГО ДЕРЖАВНОГО СТАНДАРТУ}

Кравцова I. А. Формування i розвиток навички виразного читання в учнів початкової школи в контексті нового Державного стандарту.

У статті розкрито проблему формування і розвитку навички виразного читання в учнів початкової школи відповідно до вимог нового Державного стандарту. Автором визначено ефективні методи і прийоми навчання молодших школярів виразного читання віршованих текстів, запропоновано систему завдань, спрямованих на вироблення навички аналізу ліричного твору на уроках читання.

Ключові слова: навичка виразного читання, віршований текст, аналіз ліричного твору, урок читання.

Кравцова И. А. Формирование и развитие навыка выразительного чтения у учащихся начальной школы в контексте нового Государственного стандарта.

В статье раскрывается проблема формирования и развития навыка выразительного чтения у учащихся начальной школы в соответствии с новым Государственным стандартом. Автором выделены эффективные методы и приемы обучения младших школьников выразительному чтению стихотворных текстов, предложена система заданий, направленных на формирование навыка анализа лирического произведения на уроках чтения.

Ключевые слова: навык выразительного чтения, стихотворный текст, анализ лирического произведения, урок чтения. 
Kravtsova I. A. The formation and development of elocution skills of primary school pupils in terms of new state standard.

The article deals with the problem of the formation and the development of elocution skills of primary school pupils accordiny to the requirements of the new state standard. The author studies the effective methods and techniques of teaching elocution for school pupils and saddest the system of tasks, aimed at the formation of lyrics analysis skills at readily lessons.

Key words: elocution skills, lyrics analysis, readily lesson.

В умовах реформування освіта України передбачає предмет змісту навчання i виховання, розроблення і впровадження якісно нових форм і методів, які б відповідали вимогам виховання особистості та сприяли розвитку іiі духовнх, емоційних і розумових здібностей. Ці положення закріплюються Державним стандартом початкової загальної освіти [5, с. 4$]$.

Державний стандарт визначає опанування молодшими школярами української літератури як джерела пізнання життя, засобу спілкування і прилучення до скарбниці духовності і культури, літературних надбань українського народу і народів світу, виховання патріотизму, національної самосвідомості $[4$, с. 1].

Як свідчить досвід учителів і науковців, успішне навчання в середніх і старших класах залежить від рівня сформованості читацьких умінь і навичок. Учні з низьким рівнем навички виразного читання не встигають готувати уроки як треба, їм не вистачає часу, вони не усвідомлюють змісту прочитаного матеріалу.

Початкова літературна освіта - це фундамент, на якому грунтується весь літературознавчий процес у середній школі, тому вчителеві слід не тільки навчити молодших школярів читати, а й сформувати в них уміння як аналізувати літературнохудожній твір, так і осягати його естетичну цінність. Однією $з$ найскладніших завжди була і залишається проблема повноцінного сприйняття учнями поетичного тексту, що неодноразово відзначали науковці-методисти, зокрема К. Ушинський, Н. Бунаков, В. Стоюнін, О. Савченко, В. Науменко, Г. Коваль та інші. Як свідчать спостереження, молодші школярі із задоволенням слухають, читають і вивчають напам'ять вірші, але не завжди глибоко сприймають їх. Тому формування навички виразного читання $\epsilon$ важливим завданням учителя початкових класів.

Mema cmammi: окреслити шляхи розв'язання проблеми формування навички виразного читання в молодших школярів, запропонувати ефективні методи і прийоми навчання учнів виразного читання віршованих текстів.

Виразним може бути лише читання вголос. Тому основні вимоги до нього пов'язані з інтонацією, яка охоплює складний комплекс елементів вимови, зокрема: ритм, темп, тембр, інтенсивність, логічний наголос. Виразним читанням вважається тоді, коли читець дотримується пауз, логічних наголосів, варіює пришвидшеним чи уповільненим темпом, пониженням чи підвищенням голосу під час проказування слів або речень відповідно до змісту твору.

Відомо, що віршоване мовлення характеризується передусім ритмізацією та римуванням і близьке до співу, воно діє на людину найбільше в емоційній сфері. Дитина сприймає вірші дуже легко, оскільки спів та ритм супроводжують ії з народження - від колискової матері - і багато в чому визначають іiі темперамент, менталітет, відчуття єдності з сім'єю, з нацією.

Ліричні твори потребують особливого підходу: паралельно з поясненням учителем змісту поезії повинні активізуватися знання учнів (можливо, й не 3 власного досвіду), які допоможуть їм зрозуміти, відчути і пережити почуття ліричного героя. Така взаємодія має вестися з урахуванням «зворотнього зв’язку». 
Першочергове завдання читця віршів полягає в тому, щоб збагнути всю важливість його ритму, уміти вільно ним володіти як художнім засобом. Ритм, за висловом Б. Буяльського, це «пульс вірша», осмисленість якого «дає необхідні для читання впевненість, невимушеність і різноманітність інтонацій». Завдяки ритму кожне слово у вірші несе велике смислове й емоційне навантаження, звучить виразніше, ніж у прозі. Позбавимо вірша ритмічності, і ми не побачимо його сили виразності, його краси й завершеності, а то й поетичності змісту.

Отже, правильне відчуття ритму читцем у процесі читання є засобом підсиленої виразності мови вірша, іiі емоційної напруженості, дає естетичну насолоду слухачам.

Зауважимо, що важливо також не залишати поза увагою явища евфоніки (від гр. eu - добре i phone - голос, звук), тобто краси звучання окремих мовних елементів звукових повторів: асонансу (повторення однакових голосних), алітерації (повторення однакових приголосних).

Виховання мовної культури, поваги до рідного слова, глибокого розуміння i сприйняття текстів художньої літератури найактивніше формуються під час ознайомлення 3 ліричними творами. Тому закономірно, що в читанках для учнів $1-4$ класів значне місце посідають ліричні вірші. Проте робота з ними викликає у дітей певні труднощі. Це пояснюється насамперед специфічними особливостями лірики як особливого роду художньої літератури.

Сучасний підхід до методики опрацювання ліричного вірша наголошує на умовах, за яких можливе повноцінне сприймання молодшими школярами пейзажної лірики: а) активного збагачення тезауруса учнів (тезаурус від гр. запас- сукупність понять, словник), розвитку їхньої поетичної спостережливості; б) налаштованості на сприймання; в) формування поетичного слуху, асоціативної і творчої уяви; г) уміння аналізувати образно-емоційний зміст твору; д) давати естетичну оцінку поезії та відображеній у ній дійсності; ж) активізації творчої думки учнів.

Забезпечення цих умов та знання вчителем особливостей сприймання лірики молодшими школярами веде до формування в них повноцінного естетичного сприймання пейзажної лірики.

На думку відомого педагога В. Левіна, формування поетичних здібностей молодших школярів сприяє розвитку їх творчості, розвиває уяву, мислення, мовлення.

У ході роботи над пейзажною лірикою школяр усвідомлює комунікативні можливості художніх засобів, починає бачити у собі поета. Виразне читання поетичних творів - ефективний напрям розвитку поетичних здібностей.

Одним із прийомів роботи над формуванням технічних навичок виразного читання в учнів третіх класів під час опрацювання творів $є$ аналіз поетичних творів (ліричних) 3 урахуванням жанрових особливостей.

Аналізувати ліричний твір - означає вчити школярів відтворювати в уяві картини, створені письменником, заглиблюватись у його поетичні образи, спостерігати, як змінюються почуття, настрої ліричного героя, чим вони викликані; вчити практично визначати художні засоби виразності (метафори, епітети, порівняння), а головне допомогти усвідомити авторську ідею.

Молодші школярі ще не вміють аналізувати художні твори. Здатність до аналізу та повноцінного сприйняття літературного твору, як зазначає О. Нікіфорова, «не $\epsilon$ елементарною і вродженою» [2, с. 4], вона набувається в процесі навчання. 3'ясування ідеї ліричного твору в початкових классах - це спільна пошукова діяльність учителя й учнів над твором. Однак повноцінно усвідомити ідею художнього твору можливо тільки за умови встановлення зв'язку між усіма його елементами (змістом і формою). Відтак організація роботи $з$ поетичним текстом повинна грунтуватися на принципі: від слова - 
до думки та почуття, від форми - до змісту. Учителеві необхідно допомогти учням усвідомити особливості ліричного образу, художню структуру та мову вірша, а спостереження над художньою формою допоможуть увести молодших школярів у внутрішній зміст твору, розкрити почуття, переживання, настрої ліричного героя, відчути красу віршованої мови, іiі мелодику, близькість до музики.

Розкрити складність ліричних творів учителеві допоможуть правильно дібрані методичні прийоми роботи учнів над текстом. Сучасна методична наука пропонує різноманітні прийоми аналізу вірша, схарактеризуємо найефективніші з них.

Визначення ключового слова кожної строфи. Цей прийом доцільний на початковому етапі навчання аналізу ліричних творів, оскільки формує вміння «бачити» художні образи в системі ліричного твору, «побачити» цілісну картину словеснохудожньої тканини, а через неї усвідомити ідею твору. Так, аналізуючи поезію Я. Щоголева «Осінь», учні зачитують першу строфу: Висне небо синє, синє, та не те; світить, та не гріє сонце золоте. Учитель запитує учнів: «Які рядки здалися вам найбільш яскравими в цій строфі, ніби ожили перед вами, стали відчутними образами? Які образи? Аналогічно виразно визначають у наступних строфах ключові слова (поле, листя; діброва; горобина), наприкінці вчитель робить узагальнення.

Визначення емоційної динаміки кожної строфи та настрою, 3 яким треба виразно прочитати рядки (пошук слів, якими передано стан, почуття ліричного героя; визначення причини переживання такого почуття).

Аналізуючи поезію Олександра Олеся «Довго хмарами небо покрите було...», визначаємо з учнями, які почуття передано в перших двох рядках вірша: Довго хмарами небо покрите було,/ Довго землю встеляли тумани (смуток, втома). Визначаємо причини такого почуття: учні знаходять і зачитують слова, якими автор передав цей настрій, після чого спостерігають, як змінюються почуття ліричного героя в наступних рядках: А сьогодні-дивлюсь - i весна, і тепло, I блакить, i повітря весняне (здивування та піднесений настрій). Після цього учні читають строфу так, щоб передати голосом настрій ліричного героя.

«Тлумачне читання», або читання тексту під «лінгвістичним мікроскопом» (прийом зосереджує увагу учнів на художніх засобах, формує вміння розпізнати їх, виокремлювати зі словесно-художньої тканини всього твору). Наприклад, у процесі аналізу вірша М. Рильського «Зимовий ранок» читаємо кожну строфу під «лінгвістичним мікроскопом», зупиняючись на висловах «дрімає білий ліс», «місяць ... алмази сипле», «сиві хмароньки дивуються», «ліс бачить крізь сон», «ліс шепче ... казки», щоб пояснити ці образи 3 погляду їх семантичного наповнення. Учитель допомагає учням усвідомити роль таких художніх засобів: автор за допомогою перенесення значення неживих предметів на живі «оживляє» природу, а тому образи лісу, місяця, хмароньки постають у нашій уяві живими та казковими.

Спостереження за фонетичними особливостями (звуковим оформленням, звуковими повторами, звуконаслідуванням). Наприклад, під час аналізу поезії М. Вінграновського «Літній ранок» учитель говорить учням, що природа звучить безліччю голосів, та лише чутливе вухо здатне це розпізнати. Учням пропонується знайти слова i звуки в поезії, які допомагають почути звуки природи: Дюжмелі спросоння - буц! - лобами! Попадали, ревуть в траві. I задзвонили над джмелями Дзвінки-дзвіночки лісові. Учні визначають, що повторення звуків [дж], [дз], такі слова, як ревуть, джмелі, дзвіночки задзвонили, допомагають почути звуки природи (дзижчання джмелів та почуту поетом мелодію дзвіночків).

Спостереження за особливостями поетичного синтаксису (будова речень, риторичне звертання, запитання; оформлення інтонації речень: знак оклику, запитання, 
трикрапка). Наприклад, у поезії Л. Костенко «Соловейко застудився» доцільно, щоб учні знайшли в тексті вірша окличне речення (Дощик, дощик, ти вже злива!), зачитали і 3'ясували, 3 якою метою автор уживає його. (Показати здивування, розпач i схвильованість). Учителеві важливо запитати: «До кого звертається ліричний герой? (До дощика). - Чому він двічі звертається до нього? (Підсилює увагу до образу дощика). - Як треба читати ці рядки? (Спочатку радісно - а потім схвильовано, тривожно)».

Спостереження за структурою строфи (який ритм, як римуються рядки, добір ланцюжків римованих слів, доповнення пропущених рим тощо).

Стилістичний експеримент (відбувається навмисне спотворення авторського тексту задля порівняння двох текстів та привернення уваги до авторського вибору слова). Цей прийом використовуємо задля того, щоб привчати дітей відчувати естетичну насолоду від вдало дібраного автором слова чи вислову. Для цього пропускаємо або замінюємо окремі слова, конструкції речень і на основі зіставлення допомагаємо учням усвідомити особливу виразність, точність, красу авторського поетичного тексту.

Прийом ілюстрування (словесне малювання, музичне ілюстрування, розгляд ілюстрацій). Для того, щоб розвинути уяву дітей, учителю доцільно використовувати прийом ілюстрування тексту (розглядання готових ілюстрацій, словесний та музичний супровід). Наприклад, аналізуючи поезію, можна запропонувати учням гру «Художники». Уявіть собі, що ви художники. Яку картину ви намалюєте до першої строфи? Які фарби використаєте? Чим цей малюнок відрізнятиметься від малюнка до другої строфи? Що домалюєте? Або гру «Композитори». Уявіть собі, що ви композитори. Яку музику (характер, настрій) ви написали б до цього вірша? Або запропонувати учням послухати музичний твір, після чого вони мають визначити, чи можна його вважати ілюстрацією до ліричного вірша, довести свою думку [5, с. 330].

Зіставлення художніх образів, художніх засобів, використаних різними авторами для змалювання однієї й тієї ж картини. Для прикладу вчитель може запропонувати учням зіставити художні образи грому у віршах М. Познанської «Грім» та М. Вінграновського «Грім».

Кожен із творів $є$ оригінальним явищем словесного мистецтва, тому підходи до аналітичного осмислення не повинні бути шаблонними. Адже немає універсального «ключа» до вивчення твору, а кожен ліричний текст вимагає різних прийомів аналізу. Із зазначених вище прийомів учитель має вибирати ті 3 них, які допоможуть учням не тільки зрозуміти прочитане, а й пережити і повноцінно сприйняти твір мистецтва.

У змісті початкової освіти навичкам виразного читання належить особлива роль. Тому на всіх уроках читання відбувається систематична, комплексна робота 3 формування в учнів усіх складників повноцінної читацької навички, уміння працювати 3 текстом, розвитку зв'язного мовлення.

У процесі опрацювання ліричних текстів на уроках класного і позакласного читання створюються передумови для формування самостійної читацької діяльності, літературного розвитку школярів, стимулювання елементарної творчості на основі прочитаного, розгляду творів живопису і життєвих вражень. Читаючи виразно твори, учні збагачують, уточнюють, активізують свій словник, у них формуються світоглядні уявлення, поняття, уміння висловлюватись усно і письмово.

Отже, відкритість, гнучкість, пластичність мислення, яскравість почуттєвої сфери дітей цього віку величезні. Щоб використати цей потенціал без шкоди для дитини, а навпаки зберегти і зміцнити прагнення до радості пізнання, вчителі початкової школи мають бути добре психологічно і методично підготовленими. 
Отже, навчання молодших школярів виразного читання $\epsilon$ обов'язковим складником роботи над змістом тексту, що зумовлює удосконалення читацької навички. Успішність оволодіння цим складним умінням залежить від рівня сформованості навички виразного читання, розуміння прочитаного, різноманітності і систематичності використання відповідних вправ і завдань.

\section{Література}

1. Державний стандарт початкової загальної освіти // Початкова освіта. - 2011. №18 (594). - С. 4-39. 2. Ігнатенко Н. О. Основні етапи роботи над художнім твором на уроках читання/ Н. О. Ігнатенко // Педагогіка і психологія. - 2000. - №3. - С. 3-9. 3. Олійник Г. А. Виразне читання. Основи теорії/ Г. А. Олійник. - Тернопіль : Навчальна книга - Богдан, 2007. - 224 с. 4. Савченко О. Варіативність побудови уроків читання / О. Савченко // Початкова школа. - 2006. - №9. - С. 3-8. 5. Савченко О. Я. Методика читання у початкових класах: [посіб. для вчит.] / О. Я. Савченко. - К. : Освіта, 2007. - 334 с. 6. Сухомлинський В. О. Слово рідної мови / В. О. Сухомлинський // Українська мова і література у школі. - 1987. - №7. - С. 2-7.

УДК 371.13:316.454.52:373.3-087.874

Ліна Крівщенко

\section{ОРГАНІЗАЦІЯ ІНТЕРАКТИВНОЇ ДІАЛОГОВОЇ ВЗАЕМОДЇ̈ В МАЛИХ НАВЧАЛЬНИХ ГРУПАХ}

Крівшенко Л. М. Оранізація інтерактивної діалогової взаємодії в малих навчальних групах.

У статті розглянуто досвід роботи з організації інтерактивної діалогової взаємодії молодших школярів у малих навчальних групах, зосереджено увагу на доцільності використання найбілыш уживаних у школі I ступеня інтерактивних форм і методів навчання.

Ключові слова: діалогова взаємодія, інтерактивна взаємодія, інтерактивні методи, мала навчальна група, комунікативні вміння, взаємонавчання.

Крившенко Л. Н. Организация интерактивного диалогического взаимодействия в малых учебных группах.

В статье рассматривается опыт работы по организации интерактивного диалогического взаимодействия младших школьников в малых учебных группах, сосредоточено внимание на использовании наиболее употребляемых в школе I степени интерактивных форм и методов обучения.

Ключевые слова: диалогическое взаимодействие, интерактивное взаимодействие, интерактивные методы, малая учебная группа, комуникативные умения, взаимообучение.

Krivshenko L. M. The organization of dialogue interaction in small learning groups

The article reveals the experience of organization of primary school learners' dialogue activity in small groups, the attention is paid to the most frequently used interactive forms and methods of teaching.

Key words: dialogue interaction, interaction, interactive methods, small learning group, communicative skills, mutual learning.

Провідною проблемою дидактики початкової школи є організація такої діяльності вчителя, яка забезпечувала б пізнання учнем дійсності та створення належних умов для 